\title{
THE LATTICE BROWN, KIRINIA ROXELANA (CRAMER, 1777) (LEPIDOPTERA: NYMPHALIDAE), REDISCOVERED IN CROATIA AFTER MORE THAN A CENTURY
}

\author{
TONi Koren \\ Croatian Herpetological Society - Hyla, Lipovac I n. 7., 10000 Zagreb, Croatia \\ (e-mail: koren.toni1@gmail.com)
}

Koren, T.: The lattice brown, Kirinia roxelana (Cramer, 1777) (Lepidoptera: Nymphalidae), rediscovered in Croatia after more than a century. Nat. Croat., Vol. 24, No. 2., 317-321, Zagreb, 2015.

During a field trip to southern Dalmatia, a single specimen of Kirinia roxelana was observed north of the village of Osojnik, near Dubrovnik. This is the second record of this species in Croatia, and the first accurate record after the species was mentioned for Pelješac peninsula 120 years ago. The closest known records of the species originate from Bosnia and Herzegovina, where it is also local and rare.

Key words: southern Dalmatia, distribution, fauna

Koren, T.: Mediteranski okaš, Kirinia roxelana (Cramer, 1777) (Lepidoptera: Nymphalidae), ponovno pronađen u Hrvatskoj nakon više od stoljeća. Nat. Croat., Vol. 24, No. 2., 317-321, Zagreb, 2015.

Tijekom terenskih istraživanja u južnoj Dalmaciji, jedan primjerak vrste Kirinia roxelana opažen je sjeverno od sela Osojnik kraj Dubrovnika. To je drugi nalaz ove vrste u Hrvatskoj i ujedno prvi recentni nalaz nakon povijesnog nalaza na Pelješcu prije 120 godina. Najbliži nalazi ove vrste su u Bosni i Hercegovini, no i tamo je vrlo lokalno prisutna i rijetka.

Ključne riječi: južna Dalmacija, rasprostranjenost, fauna

\section{INTRODUCTION}

Kirinia roxelana (Cramer, 1777) is a butterfly species distributed across SE Europe, Turkey, Cyprus, Israel, Lebanon, Syria, Iraq and Iran (Tolman \& Lewington, 2008). In the northern Balkans this species inhabits Croatia, Bosnia and Herzegovina and Serbia (Tolman \& Lewington, 2008). It is the only one of two species of this genus present in Europe, the second being Kirinia climene (Esper, 1783). Due to its large size and unique appearance, K. roxelana can be easily and reliably recognized when encountered, rendering misidentification, especially in the area of the northwestern Balkans, very unlikely. Accordingly, it is very peculiar that this species has been recorded only once in Croatia, 120 years ago (WERnER, 1895). After that period, no published records exist for the country, and according to the author's knowledge, this species has not been collected or observed in Croatia since that time.

The main goal of this paper is to present the first recent record of K. roxelana in Croatia, and discuss its occurrence in the country. 


\section{MATERIALS AND METHODS}

During a butterfly survey in southern Croatia, in Dubrovnik-Neretva County, in the area southeast of Pelješac Peninsula, a single specimen of $K$. roxelana (Fig. 1) was encountered near the Church of St Anne, north of the village of Osojnik $\left(42^{\circ} 43^{\prime} 24.5^{\prime \prime} \mathrm{N}\right.$ $18^{\circ} 03^{\prime} 38.0^{\prime \prime} \mathrm{E}$ ) on 16 June 2015 . The specimen was observed flying around an oak tree, in a small aggregation of trees and bushes, located along a hiking path. The small forest patch was surrounded by calcareous dry grasslands and arable land. The specimen was first photographed, then collected and placed in the author's private collection. The presence of other butterfly species was also noted.

\section{RESULTS AND DISCUSSION}

The first and only record of this species originating from the territory of Croatia is that of Werner (1895), who recorded it during his survey of Pelješac Peninsula. In that paper he lists all the species of butterflies and moths that he recorded in the area. However, mostly singular or only a few observations were given for each species, showing that the area was not indeed surveyed in detail (WeRNER, 1895). The same is true for K. roxelana, for which he mentions a record from July, but without any exact location (Werner, 1985). As the author himself states that he was located in Kučište during his visits to the peninsula, we can only assume that this is the locality where K. roxelana was observed. Afterwards, no further records were published, even though the area of southern Dalmatia was surveyed by other entomologists during the last century (e.g. NicHoll, 1899; Stauder, 1922; Neustetter, 1956; Burgermeister, 1964; Habeler 1976). In

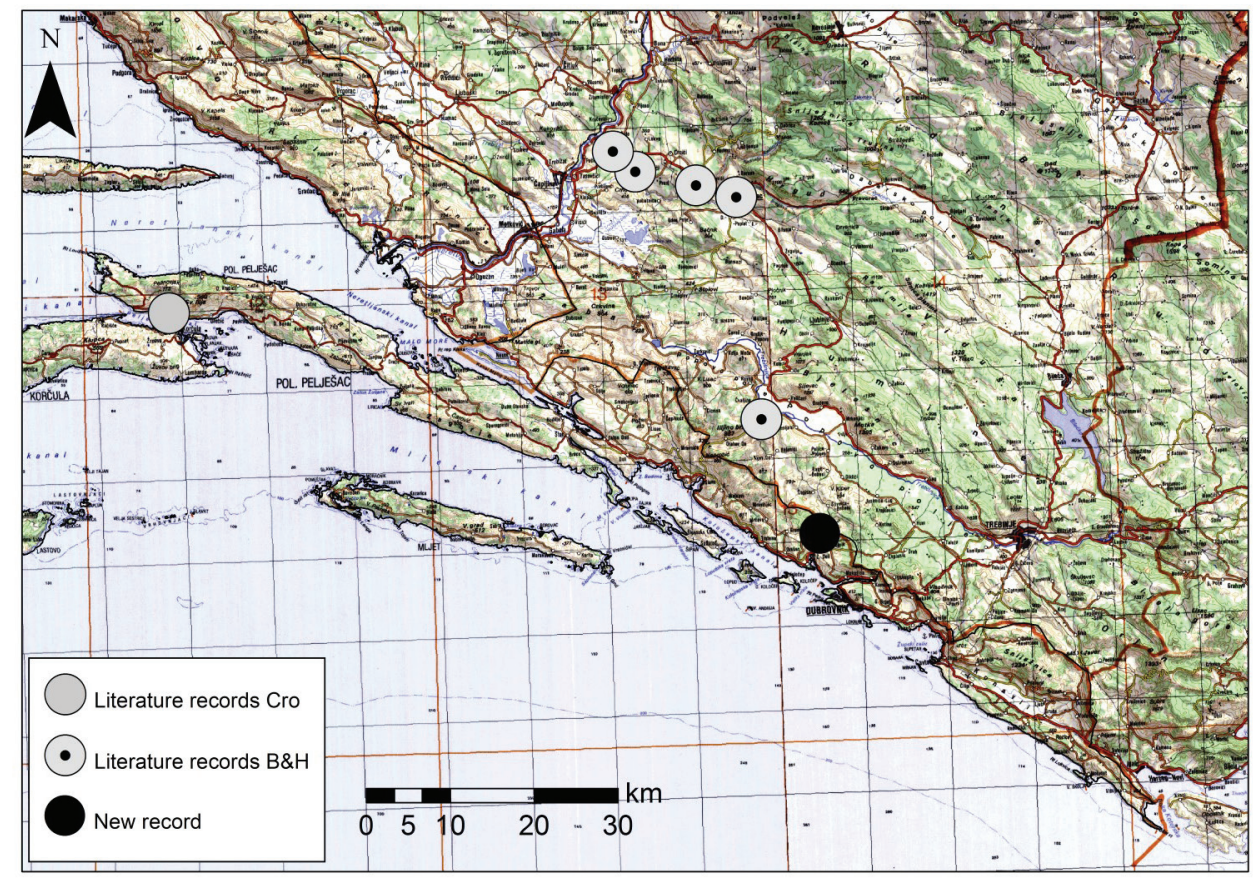

Fig. 1. Occurrence of Kirinia roxelana in Croatia (Cro) and Bosnia and Herzegovina (B\&H) 


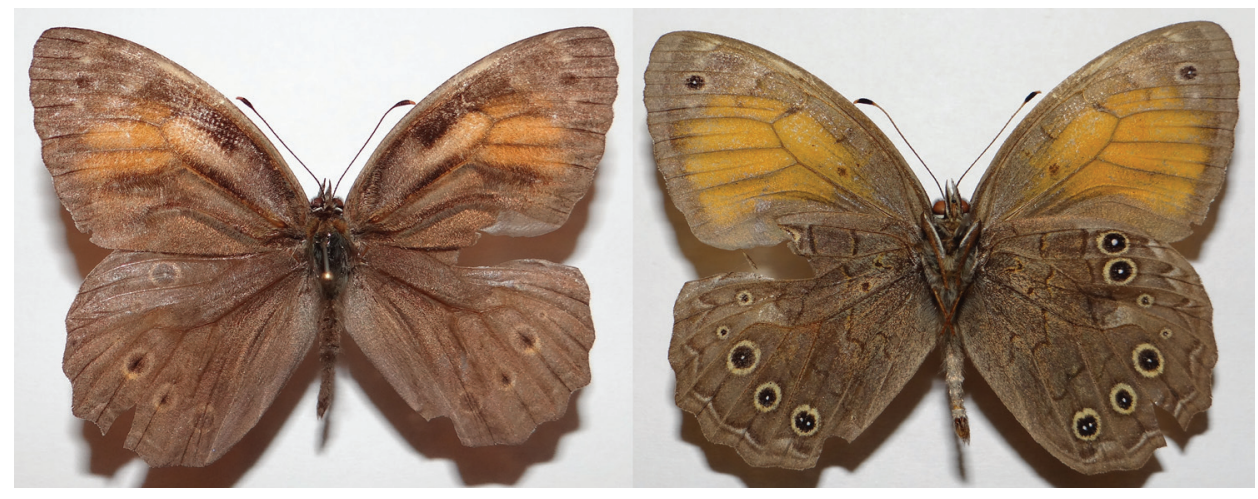

Fig. 2. Upper- and underside of Kirinia roxelana from the village of Osojnik, Croatia

the neighbouring Bosnia and Herzegovina this species was until recently known only from two localities, Domanovići and Stolac (RebeL, 1904). Recently the species has been rediscovered an one historical and several additional localities (Lelo 2008; Žujo Zeкić \& LELO, 2012). This exemplifies that the species is more widespread in Bosnia and Herzegovina than was previously known, but still limited to a small area in Herzegovina.

The new record from Croatia is only $17 \mathrm{~km}$ distant from the nearest locality, Zavala, in Bosnia \& Herzegovina (ŽUJo ZeKIĆ \& LELO, 2012), and represents only a small expansion in the known distribution, but on the other hand it is a valuable confirmation of occurrence in the country. If one takes into consideration all the known records from Bosnia \& Herzegovina and Croatia, it seems probable that the Neretva Valley represents the northern distribution point of this species (Fig. 2).

This recent rediscovery gives more credit to the historical records, even if this species was not found anywhere in Croatia else despite intensive search. Indeed it is questionable if the species is a permanent resident in Croatia. It is possible that it is a vagrant, as they are strong fliers and not restricted th any particular habitat. Further surveys of the same locality during the same day were unsuccessful, and no other specimens were observed.

In the red list of butterflies of Croatia, this species' status was not evaluated (ŠAšić et al., 2013) but because it is based on only two known records it should be considered Data Deficient (DD).

Another 29 butterfly species were observed in the same locality: Thymelicus sylvestris (Poda, 1761), Thymelicus acteon (Rottemburg, 1775), Ochlodes sylvanus (Esper, 1777), Iphiclides podalirius (Linnaeus, 1758), Leptidea sinapis (Linnaeus, 1758), Pieris rapae (Linnaeus, 1758), Pieris ergane (Geyer, 1828), Colias croceus (Fourcroy, 1785), Aporia crataegi (Linnaeus, 1758), Cupido minimus (Fuessly, 1775), Celastrina argiolus (Linnaeus, 1758), Iolana iolas (Ochsenheimer, 1816), Scolitantides orion (Pallas, 1771), Satyrium ilicis (Esper, 1779), Plebejus argus (Linnaeus, 1758), Polyommatus icarus (Rottemburg, 1775), Argynnis niobe (Linnaeus, 1758), Brenthis hecate (Dennis \& Schiffermüller, 1775), Melitaea didyma (Esper, 1778), Limenitis reducta (Staudinger, 1901), Lasiommata megera (Linnaeus, 1767), Lasiommata maera (Linnaeus, 1758), Coenonympha arcania (Linnaeus, 1761), Coenonympha pamphilus (Linnaeus, 1758), Maniola jurtina (Linnaeus, 1758), Melanargia larissa (Geyer, 1828), Satyrus ferula (Fabricius, 1793), Hipparchia semele (Linnaeus, 1758) and Brintesia circe (Fabricius, 1775). 
From these species, the records of I. iolas and M. larissa are worth mentioning. The largest Lycanidae species in Croatia, I. iolas, has a Mediterranean occurrence and it is present mostly along the coastline and on some Adriatic islands. This species is known to migrate, and has been recorded even on peak of Mt. Velebit (Lorković, 2009). In the surveyed area it was very common, and few dozen males and several females were observed faying around their larvae food plant, Colutea arborescens Linnaeus 1753.

The second interesting species, M. larissa, is distributed locally in the coastal region of Croatia (Lorković, 2009). In the surveyed area only few specimens were observed.

\section{CONCLUSIONS}

In the checklist of butterfly fauna of every country there are at least some species the occurrence of which is considered unreliable either due to lack of recent records or potential misidentification. In the last decade, several such species were omitted from the checklist of butterflies of Croatia (e.g. Leptidea duponcheli (Staudinger, 1871), Kučınić et al. (2009) and Hipparchia senthes (Fruhstorfer, 1908), Konen et al. (2013). However, several such species are still present in the recent checklist (ŠAšić \& MiнocI, 2011). For example no recent valid records exist for Papilio alexanor (Esper, 1800), Zerynthia cerisy (Godart, 1824), Colias myrmidone (Esper, 1781) or Pseudochazara anthelea (Hübner, 1824). And while some species like C. myrmidone may have become regionally extinct in the country, the confirmation of $K$. roxelana gives hope that some of the species mentioned above will be rediscovered in Croatia in the near future.

Received September 16, 2015

\section{REFERENCES}

Burgermeister, F., 1964: Makrolepidopteren aus dem Raume Dubrovnik (Süddalmatien, FVR Jugoslavien). Zeitschrift der Wiener Entomologischen Gesellschaft 49, 137-152.

Habeler, H., 1976: Beiträge zur Lepidopterenfauna Dalmatiens. Acta Entmologica Jugoslavica 12(1-2), 67-87.

Koren, T., Črne, M. \& Španić, R., 2013: On the questionable record of the Balkan Grayling, Hipparchia senthes (Fruhstorfer, 1908), in Croatia (Lepidoptera: Nymphalidae, Satyrinae). Nachrichten des Entomologischen Vereins Apollo, 34(3), 133-136.

Kučinić, M., Pelić, D., Vajdić, M. \& GJurašIn, B., 2009: An interesting specimen of Leptidea duponcheli (Staudinger, 1871) in the Central butterfly collection of the Croatian natural history museum in Zagreb. Natura Croatica, 13 (1), 95-100.

Lelo, S., 2008: Dnevni leptiri Bosne i Hercegovine (Lepidoptera: Papilionoidea i Hesperioidea): Ključ za determinaciju vrsta sa osnovnim monografskim podacima. Univerzitetska knjiga. Prirodno-matematički fakultet Univerziteta u Sarajevu.

LoRкоvić, Z., 2009 (unpublished manuscript from 1954): The Rhopalocera fauna of Croatia with special respect to the fauna of Plitvice Lakes. Entomol. Croat. 13, 15-78.

Neustetter, H., 1956: Sammelreisen nach Dalmatien (Jugoslavien). Entomologisches Nachrichtenblatt 3(3), 4-8.

Nicholl, M., 1899: Butterflies hunting in Dalmatia, Montenegro, Bosnia and Herzegovina. The Entomologist's Record and Journal of Variation, 11 (1), 1-8.

Tolman, T. \& Lewington, R., 2008: Collins butterfly guide, Harper Collins Publisher London, 384 pp.

Rebel, H., 1904: Studien über die Lepidopterenfauna der Balkanländer. II. Teil. Bosnien und Herzegowina. Annalen des K.K. Naturhistorischen Hofmuseums 36, 97-377.

StAuder, H., 1922: Die Schmetterlingsfauna der illyro-adriatischen Festland- und Inselzone (Faunula Illyro-Adriatica). Zeitschrift für wissenschaftliche Insektenbiologie Berlin 17 (1/2), 14-21, (3/4), 58-64, (5/6), 83-92, (7/8), 135-147, (9/12), 165-176. 
ŠAšrć, M. \& MıносI, I., 2011: Annotated checklist of Croatian butterflies with vernacular names. Natura Croatica 20(2), 425-436.

ŠAšıć, M., MıнocI, I. \& KučınIĆ, M., 2013: Crveni popis danjih leptira Hrvatske. Državni zavod za zaštitu prirode, Ministarstvo zaštite okoliša i prirode, Zagreb.

Werner, O., 1895: Bilješke o makro-lepidopterama, prikupljenim na poluostvu Pelješcu. Glasnik zemaljskog muzeja Bosne i Hercegovine 7, 207-214.

Žujo Zeкić, D., \& Lelo, S., 2012: Novi nalaz vrste Kirinia roxelana Cramer, 1777 (Insecta: Lepidoptera, Nymphalidae) na lokalitetu Masline (Općina Stolac). Međunarodni naučni skup “Struktura i dinamika ekosistema dinarida - Stanje, mogućnosti i perspektive", Sarajevo, 15.-16. juni, Akademija nauka i umjetnosti Bosne i Hercegovine, Sarajevo, Bosna i Hercegovina, Posebna izdanja, CXLIX Odjeljenje prirodnih i matematičkih nauka, Zbornik radova 23, 259-264.

\section{SAŽETAK \\ Mediteranski okaš, Kirinia roxelana (Cramer, 1777) (Lepidoptera: Nymphalidae), ponovno pronađen u Hrvatskoj nakon više od stoljeća}

\section{T. Koren}

U fauni dnevnih leptira gotovo svake države postoji određeni broj vrsta za koje postoji jedan ili svega nekoliko najčešće povijesnih nalaza. Mediteranski okaš, Kirinia roxelana, jedna je od takvih vrsta. Do sada je za područje Hrvatske bio poznat samo jedan nalaz s neznane lokacije na poluotoku Pelješcu (Werner, 1985). Tijekom terenskih istraživanja južne Dalmacije u lipnju 2015. godine u okolici Dubrovnika opažen je i sakupljen jedan primjerak ove rijetke vrste. Taj recentni nalaz ukazuje na to da je vrsta još uvijek prisutna u Hrvatskoj, no vjerojatno vrlo lokalna i rijetka. U susjednoj Bosni i Hercegovini vrsta je rijetka te postoje svega dva povijesna (Rebel, 1904) i nekoliko recentnih nalaza (Žujo ZeKić \& Lelo, 2012). Ukoliko uzmemo u obzir oba poznata nalaza iz Hrvatske, dolina rijeke Neretve predstavlja sjevernu granicu rasprostranjenosti ove vrste u Hrvatskoj. Ono što je posebno zanimljivo je činjenica da vrsta prošlih godina nije bila zabilježena na tom području, unatoč mnogobrojnim terenskim posjetima u različita godišnja doba. 